\title{
The Europeans who came back: Kurdish refugees in Finland
}

\section{Adél Furu}

Babeș-Bolyai University, Cluj-Napoca, E-mail: furuadel@yahoo.com

\begin{abstract}
This article examines the extent to which cultural continuity represents the Kurdish immigrants living in Finland and concentrates on those cultural practices and traditions of the Finnish society that seem difficult to be accepted by the Kurdish immigrants. The research questions addressed in this study are as follows: To what extent the new Kurdish refugees, as members of a non-Western culture, remain static and traditional? Do they resent the Nordic values or on the contrary, they try to conform the Finnish values? We will examine whether, at least related to some aspects of the Kurdish tradition, we can speak about the death of the tradition or it is premature to declare that.

The present study wants to give an overview of the kind of Kurdish folk tradition that lives in Finland and of the nature of the Kurdish individuals' relationship to their own cultural experience. We examine if the members of the Kurdish community living in Finland have learnt to act according to the standards of behaviour required by the Finnish society or the practices adopted by them differ from how the people of Finnish background behave. In many cases, adult Kurdish individuals bring their own culture to Finland but it is often the culture of violence that goes with them to the new country. Methodologically I rely on cultural, migration and social life studies in this article. In addition, I attend to identity and family studies.
\end{abstract}

\section{Rezumat}

Acest articol examinează măsura în care continuitatea culturală reprezintă imigranții kurzi care trăiesc în Finlanda, și se concentrează asupra acelor practici și tradiții culturale ale societății finlandeze care par dificil de acceptat de către imigranții kurzi. Intrebările de cercetare abordate în acest studiu sunt următoarele: În ce măsură noii refugiați kurzi, ca membri ai unei culturi non-occidentale, rămân statici și tradiționali? Se opun valorilor nordice sau, dimpotrivă, încearcă să se conformeze valorilor finlandeze? Vom examina dacă, cel puțin în legătură cu unele aspecte ale tradiției kurde, putem vorbi despre moartea tradiției sau este prematur să declarăm acest lucru.

Prezentul studiu dorește să ofere o imagine de ansamblu a tipului de tradiție populară kurdă care trăiește în Finlanda și a naturii relației indivizilor kurzi cu propria lor experiență culturală. Studiem dacă membrii comunității kurde care trăiesc în Finlanda au învățat să acționeze in conformitate $\mathrm{cu}$ standardele de comportament cerute de societatea finlandeză, sau practicile adoptate de aceștia diferă de modul in care se comportă poporul finlandez. In multe cazuri, indivizii kurzi adulți își aduc propria cultură în Finlanda, dar adesea este cultura violenței care-i însoțește în noua țară.

Din punct de vedere metodologic, mă bazez pe studii culturale, migraționale și sociale în acest articol. In plus, apelez la studiile de identitate și de familie.

Keywords: Kurdish refugees, Finland, conforming or resenting the Finnish values, culture of violence, integration 
CC BY-SA License (https://creativecommons.org/licenses/by-sa/2.0)

This paper has been presented at the 10th International Conference on Baltic and Nordic Studies in Romania entitled Dissent versus Conformism in the Nordic, Baltic and Black Sea Areas, “Ovidius" University of Constanţa, 6-8 June 2019.

\section{Key concepts related to the issue of immigration}

I approach the topic through the themes of culture, ethnicity, language and religion. Young Kurdish people's experiences are also determined by cross-border relationships. Toivanen ${ }^{1}$ identifies a transnational state that affects the immigrants' realities and understanding and that is localized in the country of origin - Kurdistan, the current place of residence - Finland and some other Kurdish communities existing worldwide. The concept of transnationalism constitutes the theoretical basis for the present study as transnationalism is the factor that models the Kurdish people's family connections. Häkkinen ${ }^{2}$ associates to transnationalism those manifold political, economical, cultural and social cooperation that bond people beyond the state borders. According to Bryceson and Vuorela's definition, a transnational family refers to a family whose members reside at least for a while apart but maintain and create a sense of community across national borders. ${ }^{3}$

Furthermore, it is essential to define the concept of refugee. A refugee is a person who "owing to well-founded fear of being persecuted for reasons of race, religion, nationality, membership of a particular social group or political opinion, is outside the country of his nationality and is unable or, owing to such fear, is unwilling to avail himself of the protection of that country; or who, not having a nationality and being outside the country of

\footnotetext{
${ }^{1}$ Mari Toivanen, 'Kotona Turussa ja Suomessa? Kurdinuorten neuvottelua kuulumisesta ja identiteeteistä', Tutkimuskatsauksia 7 (2013a).

2 Anne Häkkinen, "Contemporary Kurdish families in Finland: Traditional, modern or something else?", in Current Issues in European Cultural Studies, ed. M. Fredriksson (Linköping: Linköping University Electronic Press, 2011), 55-62.

3 Elina Lehtonen, "Kurdit Turussa. Yhteisöllisyyden rakentuminen diasporassa", https://tampub.uta.fi/bitstream/handle/10024/92522/gradu00451.pdf?sequence=1,_accessed at 13.05.2019.
} 
his former habitual residence as a result of such events, is unable or, owing to such fear, is unwilling to return to it." 4

From a sociological view, Wahlbeck considers all those people refugees who feel themselves to be refugees. A refugee is a person who has a special relationship with both the country of origin and the country of residence. He differs from another kind of immigrant in the sense that his departure from the home country happened in practice when forced, and he was often not free to choose his current country of residence. Kunz contrasts the refugees and immigrants expressing that the reluctance to leave and the lack of positive motivation to settle elsewhere is typical for refugees and separates them from voluntary immigrants. ${ }^{5}$

Another central concept in immigration research is integration that, according to Wahlbeck, refers to the relationship between the immigrant and the new country of residence, where the immigrant can maintain his or her own identity and belong to an ethnic minority group and at the same time participate in the activities of the mainstream society. Yet, integration for Valtonen means participation in working life and education, social interaction and organized activities in the fields of culture, politics or religion and intercultural encounters. ${ }^{6}$

\section{Finnish bureaucracy and lack of information}

Häkkinen $^{7}$ depicts the Kurdish immigrants ${ }^{8}$ living in Finland as traditional, as opposed to the Finns who are part of a modern culture. Marginalized Kurds and migration are handled with skepticism by the Finnish government. Some Kurdish immigrants even think that the Finnish bureaucracy is probably one of the most difficult in the world. Quite often, they come across racist and xenophobic attitudes while trying to get a job or maintaining it. Family reunification proves to be entangled to the extent that Kurdish immigrants expect that they will never get their families to Finland.

\footnotetext{
${ }^{4}$ Convention and Protocol Relating to the Status of Refugees, art. 1, A. (2).

${ }^{5}$ Lehtonen 2004.

${ }^{6}$ Ibid.

${ }^{7}$ Häkkinen 2011.

${ }^{8}$ Immigrants form about $5 \%$ of the Finnish population. Kurdish people form one of the largest immigrant groups in Finland (estimated 10.000 Kurds).
} 
Moreover, these immigrants are separated from their families who live in a war zone. In this context, it is doubtful that these migrants can become contented, dynamic and pragmatic citizens.

Some Kurdish immigrants have complained upon arriving to Finland that there was little information about their rights which showed what they could do and what not. They lacked any kind of previous knowledge about their rights in the new country and this was perceived as a negative thing during the immigration process. Information and their availability were considered significant things which could show the paths ahead. In the immigrants' opinion, a person who moves to a new country and a new environment is like a child who needs more help, information and assistance.

\section{Cultural continuity for those who are eternal foreigners}

Among youth, Kurdishness is considered the key identity due to the fact that the criteria for Finnishness are regarded too tight. Häkkinen's focus is on cultural continuity among the Kurdish individuals and on the dynamics of transnational marriages observing that Kurdish immigrants, especially women, generally do not choose to marry Finnish men but instead opt for a partner from their own society who is neither a European nor a Christian.

According to Kiuru' ${ }^{9}$, young Kurdish immigrants in Finland find it an opportunity to be able to benefit from the strengths of both cultures but on the other hand there is a risk that mainly the weaknesses of those cultures will be embraced. As young migrants spend their lives in a particular cultural space, they point out the problematic experience that in fact, they do not belong anywhere. This is due to the fact that in Finland the Kurdish migrant is considered an eternal foreigner while in Kurdistan he is viewed as "the European who came back"10.

\footnotetext{
${ }_{9}^{9}$ Riikka Kiuru, "Diasporinen tietoisuus, arjen kokemukset ja kansanperinne - Tulkintoja Suomessa kurdien asuvien perinnesuhteesta", https://helda.helsinki.fi/bitstream/handle/10138/19530/diaspori.pdf?sequence=2\&isAllowed= $\mathrm{y}$, accessed at 26.05.2019.

10 "se eurooppalainen, joka tuli takas". Ibid., 50. Translated by Adél Furu.
} 
Kiuru shows that Kurdish cultural traditions (colourful national costume, fairy tales) are essential for young immigrants who live in a Finnish cultural environment. They try to understand and own the Kurdish folklore and seek to discover in it something distinctive from the cultural elements that are known in Finland. Young Kurdish migrants want to know and remember those details of their culture that differ from the Finnish tradition and are unknown and exotic. Owning and embracing something authentic and peculiar that sets them apart from the Finnish cultural heritage improves their self-esteem.

\section{Confrontations during the social integration}

Those Kurdish individuals who have tried to seek asylum in Finland have faced many challenges when starting a new life in Finland: they have arrived in a foreign country with an unknown language, culture and even different climate. Their lives were eased when they started participating in Finnish language courses, they acquired Finnish friends and they gathered their own courage. In the migration process they are positively surprised by the Finnish system and law, the social well-being and equality. They are willing to study more Finnish and learn more about the Finnish culture, society and working life. They want to be active members of the society and participate in various social events and gather information about the history of Finland.

Some of the Kurdish immigrants have experienced that some of the Finns have accepted their move more easily, while others opposed their move. Thus the immigrants had to learn patience and contribute actively to their adaptation. These people would need numerous trainings and events to help their social integration. It seems that the biggest challenge is when a very young immigrant is faced with the fact that he or she is the only darkskinned person in kindergarten, at school or in working life. Above all, prejudices are not missing in these contexts and other children's parents may be anti-immigrant. Along the years spent in Finland, these immigrants learn that they do not need to compete with the locals and prove to be suitable candidates for the Finnish residency or citizenship. 
In some cases, the realities and expectations of the Kurdish and Finnish societies have clashed and immigrant children at school have had to fear bullying. Nevertheless, when children of the same background had met at school much of the fear disappeared because in their culture people from the same country were defended even though they were not close friends. Another difficulty encountered has been the lack of understanding from the Finnish teachers related to contrasting backgrounds at school which led to the inability to organize training with different groups. Kurdish pupils are witnesses even nowadays of the teachers' inappropriate behaviour due to these issues.

A lot of identity problems have been created along the kindergarten and school years due to the scarcity of support for dealing with racism. For it was burdensome for Kurdish children to live at home as in Kurdistan while at school try to be unnoticeable not to be abused by anyone.

Kurdish children in Finland have grown up without the skills and education of a traditional village community and have not adopted its values; instead, young people have inspired from the mainstream culture; therefore, immigrants need continuous cultural interpretation and support to assess different requirements and expectations. We show how different cultures and values bring contradictory ideas to young people. Young people who are born in Finland want to live like Westerners, but their families expect them to behave in a traditional way. Children cannot combine these two different worlds because the habits and expectations are completely different from their parents'. Toivanen ${ }^{11}$ notes that young Kurdish people have adopted different cultural influences and traditions from Kurdistan but have become bilingual through the Finnish school system.

Huttunen asserts that the refugees' physical appearance and otherness, namely not belonging to "the white landscape of Finland"12, or a different accent often constructs a barrier in the integration process. Kurdish

\footnotetext{
11 Toivanen 2013a.

${ }^{12}$ As cited in: Mari Toivanen, 'Language and negotiation of identities among young Kurds in Finland', Nordic Journal of Migration Research 3(1) (2013b): 27-35, 31.
} 
children may face discrimination based on their look and not their actions or lack of language knowledge.

\section{Culture of violence brought to Finland}

Very often, adult Kurds bring their own culture to Finland but it is often the culture of violence that goes with them. Jantunen (2017) ${ }^{13}$ emphasizes that the Finnish state and authorities should not simply acknowledge that violence is intertwined with culture. According to some Kurdish immigrants, Finnish authorities should not be too tolerant and concessive regarding foreign cultures and religions, but in fact, authorities should show a more critical attitude towards religions and cultures. Additionally, Jantunen points out that although Kurdish men themselves are victims of their controlling, strict and religious culture, when moving to Finland they have to be aware that they must conform the Finnish culture and values. In this sense, domestic violence should be eliminated at least in the receiving country.

Strandén ${ }^{14}$ argues that even some Kurds themselves disagree with the fact that the traditional division of labour in the Kurdish families is often kept in Finland too. This means that Kurdish women are not allowed to study and work, though when these immigrants move to Finland they should accept equality, and women should also get to work and not expect that the state pays them in Finland for remaining at home.

As the quotation below suggests, domestic violence against migrant Kurdish women is not eradicated even in Finland, moreover the violent behavioural pattern is passed on to the next generations although it has many social consequences, it is a crime in Finland, a violation of human

\footnotetext{
${ }^{13}$ Heikki Jantunen, "“Kukaan ei uskalla kritisoida kulttuuria tai uskontoa” - Suomessa asuva kurdi puhuu väkivallasta naisia kohtaan HS:lle", https://www.verkkouutiset.fi/kukaan-eiuskalla-kritisoida-kulttuuria-tai-uskontoa-suomessa-asuva-kurdi-puhuu-vakivallastanaisia-kohtaan-hslle-68369/, accessed at 27.05.2019.

${ }^{14}$ Mika Strandén, "Syyrian kurdi Sulaiman Sulaiman tuli Suomeen jäädäkseen - "Ajattelin etten koskaan tule täysin suomalaiseksi, mutta voin oppia kielen ja kulttuurin."', https://esaimaa.fi/uutiset/lahella/73c5362d-577c-453d-95f1-55efd2975c20, accessed at 10.05.2019.
} 
rights and equality, and it is extremely costly for the Finnish state. Ser quotes a migrant Kurdish woman:

“[...] Now we are in Finland. I want to dwell and live in peace and be safe. But the man's violence is here too. I just want the violence to end. I want the authorities to use the Finnish legislation or, by some means, the domestic violence to end. I want to go to school and I want to get a profession, I want to go to work."15

\section{Conclusions}

Young Kurdish people living in Finland have been influenced by the Finnish culture and school system. In the traditional Kurdish community, they had learnt that the family's interests lie above the individual's interests but when moving to the modern Finnish society, they are nurtured by selfinitiative and independence. The truth is that those Kurdish individuals who move to a modern Nordic country have to face a great pressure and they are not capable of adaptation in a short period of time. Therefore, Saarinen ${ }^{16}$ claims that Kurdish immigrants need continuous cultural interpretation and support to assess the requirements and expectations of the Finnish culture.

More experienced Kurdish immigrants who have not come recently to Finland realize that they should critically relate to old information, their attitudes, wishes and religion because Finland offers new circumstances and presents different requirements. Under these circumstances, their previous knowledge might be old and unfunctional in the receiving country.

\footnotetext{
15 “Nyt olemme Suomessa. Haluan asua ja elää rauhassa ja olla turvassa. Mutta täälläkin on miehen tekemää väkivaltaa. Haluan vain, että väkivalta loppuu. Haluan, että viranomaiset käyttävät Suomen lainsääntöä tai jollakin keinolla perheväkivalta loppuu. Haluan mennä kouluun ja haluan saada ammatin, haluan mennä töihin.". Ser Kiymet, "'Kurdinainen nyrkin ja hellan välissä". Suomessa asuvien Turkin kurdinaisten kokema pari- ja lähisuhdeväkivalta", https://www.theseus.fi/bitstream/handle/10024/123626/Ser_Kiymet.pdf?sequence $=1$, accessed at 13.05.2019, 59, translated by Adél Furu.

16 Tuija Saarinen, "Yleiset kulttuurierot ja stereotypisointi: Kurdilainen perhe- ja tapakulttuuri",

http://www.oppi.uef.fi/aducate/projektit/monikko/Kurdiartikkeli Saarinen.pdf, accessed at 9.05.2019.
} 
Willing to adopt the rules and customs of the country where the refugee lives is part of the integration discourses and immigration debates. Most of the young Kurds defend their positions in the Finnish community by having good Finnish language skills and at the same time avoid being identified as refugees or immigrants. However, in most of the cases the distinctive physical appearance is the principal factor for not being able to identify themselves as Finns (Toivanen 2013b) ${ }^{17}$.

Young and clever refugees try to balance Kurdistan and Finland in their transnational lives. Their ambivalent position is levelled by approving the Finnish culture and by removing morally questionable Finnish practices and attitudes, for instance the utilization of alcohol and impoliteness towards their parents. The atmosphere of the Finnish capital is described by the immigrants as discriminatory and racist. Boys who had no white skin colour have been suspected of criminality in the Finnish cities and therefore, ambitious and educated Kurdish youth tried to avoid immigrant groups and get a degree in order to better comply with the 'norms' of the ordinary Finnish society. They also claim equal opportunities with the majority population. In contrast, very few refugees emphasize their transnational networks and plan to escape from Finland. Kurdish refugees recreate and redefine what Haikkola ${ }^{18}$ has called the kin-based transnational networks that even provide favourable circumstances for a getaway from the country of settlement.

Kurdish refugees have to decide in time whether they maintain their own culture or they become Finns to a certain extent. The development and adjustment of their actions depend on the Finnish society and integration policies. In a new life situation, they have to decide how much to absorb from the Finnish culture and how much they want to keep the Kurdish cultural values. Confident and determined refugees try to take what is good from both cultures while keeping their own identities.

In Finland, even the structure of the Kurdish family changes according to the Finnish parents-children model while extended families,

\footnotetext{
17 Toivanen 2013b.

${ }^{18}$ Lotta Haikkola, 'Transnational and local negotiations of identity: Experiences from secondgeneration young people in Finland', Nordic Journal of Migration Research 1(3) (2011): 156-165.
} 
98 | Revista Română de Studii Baltice şi Nordice / The Romanian Journal for Baltic and Nordic Studies 11 (1)

which include aunts, uncles and cousins, disappear. As well, childcare in line with the Finnish model can sometimes cause disputes between the Kurdish spouses, especially if one of them disagrees with it ${ }^{19}$.

${ }^{19}$ Heini Amiina Kuitunen, "Strengths and coping of Iraqi Kurdish women in Pirkanmaa, Finland", https://www.theseus.fi/bitstream/handle/10024/57080/Kuitunen Heini_Amiina.pdf?sequenc e=1\&isAllowed =y, accessed at 12.05.2019. 


\section{References:}

\section{Books and articles:}

Haikkola, Lotta. 'Transnational and local negotiations of identity:

Experiences from second-generation young people in Finland.' Nordic Journal of Migration Research 1(3) (2011): 156-65.

Häkkinen, Anne. 'Contemporary Kurdish families in Finland: Traditional, modern or something else?' In Current Issues in European Cultural Studies. Ed. Martin Fredriksson. Linköping: Linköping University Electronic Press, 2011, 55-62.

Toivanen, Mari. 'Kotona Turussa ja Suomessa? Kurdinuorten neuvottelua kuulumisesta ja identiteeteistä.' Tutkimuskatsauksia 7 (2013a).

Toivanen, Mari. 'Language and negotiation of identities among young Kurds in Finland.' Nordic Journal of Migration Research 3(1) (2013b): 27-35.

\section{Web postings:}

Jantunen, Heikki, "'Kukaan ei uskalla kritisoida kulttuuria tai uskontoa" Suomessa asuva kurdi puhuu väkivallasta naisia kohtaan HS:lle", https://www.verkkouutiset.fi/kukaan-ei-uskalla-kritisoidakulttuuria-tai-uskontoa-suomessa-asuva-kurdi-puhuu-vakivallastanaisia-kohtaan-hslle-68369/, accessed at 27.05.2019.

Kiuru, Riikka, "Diasporinen tietoisuus, arjen kokemukset ja kansanperinne

- Tulkintoja Suomessa asuvien kurdien perinnesuhteesta", https://helda.helsinki.fi/bitstream/handle/10138/19530/diaspori.pdf? sequence $=2 \&$ isAllowed $=\mathrm{y}$, accessed at 26.05.2019.

Kuitunen, Heini Amiina, "Strengths and coping of Iraqi Kurdish women in Pirkanmaa, Finland",

https://www.theseus.fi/bitstream/handle/10024/57080/Kuitunen Hei ni Amiina.pdf?sequence=1\&isAllowed $=y$, accessed at 12.05.2019.

Lehtonen, Elina, "Kurdit Turussa. Yhteisöllisyyden rakentuminen diasporassa",

https://tampub.uta.fi/bitstream/handle/10024/92522/gradu00451.pdf ?sequence $=1$, accessed at 13.05.2019.

Saarinen, Tuija, "Yleiset kulttuurierot ja stereotypisointi: Kurdilainen perhe- 
100 | Revista Română de Studii Baltice şi Nordice / The Romanian Journal for Baltic and Nordic Studies 11 (1)

ja tapakulttuuri", http://www.oppi.uef.fi/aducate/projektit/monikko/Kurdiartikkeli S aarinen.pdf, accessed at 9.05.2019.

Ser, Kiymet, "'Kurdinainen nyrkin ja hellan välissä". Suomessa asuvien Turkin kurdinaisten kokema pari- ja lähisuhdeväkivalta", https://www.theseus.fi/bitstream/handle/10024/123626/Ser_Kiymet. pdf? sequence=1, accessed at 13.05.2019.

Strandén, Mika, "Syyrian kurdi Sulaiman Sulaiman tuli Suomeen jäädäkseen - "Ajattelin etten koskaan tule täysin suomalaiseksi, mutta voin oppia kielen ja kulttuurin."', https://esaimaa.fi/uutiset/lahella/73c5362d-577c-453d-95f155efd2975c20, accessed at 10.05.2019. 